Falun Gong and the Future of China, by David Ownby.

Oxford and New York: Oxford University Press, 2008. xi, 291 pp. US\$29.95, cloth.

Book review by David A. Palmer

PRE-PUBLICATION VERSION

Published in Pacific Affairs (2009)

Falun Gong and the Future of China is a work directed at general readers and scholars alike, providing a rich context for interpreting the Falun Gong issue in terms of China's religious, political and cultural history, the challenges facing China at present, and the future evolution of a globalized Chinese society. Written in clear, engaging and often humorous prose, the work is an easy and most pleasant read, accessible to a broader general audience, without compromising on scholarly standards: synthesizing materials from a bewildering range of fields (ancient history, peasant rebellions, religious revivals, Chinese medicine, the qigong movement, diaspora studies, the Internet in China, Communist Party politics, and more) and challenging historiographical traditions, the work engages with scholarly debates and offers new perspectives on the interpretation of Chinese history, making it of great interest to specialists as well. Indeed, the author presents himself to the general public as offering the perspective of a professional historian on a highly sensationalized issue, and adroitly pulls it off.

Ownby uses the Falun Gong issue as a prism through which the entire narrative of China's modern history should be rethought. The second chapter places Falun Gong in the context of the long history of popular Chinese religious movements spanning over two millenia, looking at the historical and sociological continuities between a certain type of religious movement ("redemptive societies"), including Falun Gong, from the perspective of the groups themselves, rather than using the distorting categories (sect, heterodoxy) used by different regimes of the Chinese state. Falun Gong thus appears as the latest manifestation of an enduring tradition in Chinese religiosity, and already one of the dominant forms of Chinese religiosity throughout much of the $20^{\text {th }}$ century, which has been almost completely ignored by scholars of Chinese religion and society alike. In the next chapter, Ownby situates the appearance of Falun Gong within the immediate context of the qigong boom of the 1980's and early 1990's - Falun Gong was one of thousands of post-Mao "redemptive societies" which focused on qigong body cultivation regimens and, for a period, enjoyed the encouragement and protection of high-level Party leaders. Chapter 4 is a discussion of Li Hongzhi's biography and teachings, based on a careful and nuanced study of his published lectures and writings. This is followed in the next chapter by an analysis of Falun Gong practitioners among the Chinese diaspora, 
based on the author's own ethnographic fieldwork in Toronto, Montreal, Houston, New York and Boston. Most diasporic practitioners are immigrants from mainland China with high levels of education and professional backgrounds, who joined the movement after it was banned in China in 1999. While such data can't be used to generalize about practitioners in the Chinese mainland, about whom it is now impossible to do research, the results are still of great value owing to the crucial role diaspora practitioners now play in Falun Gong as a transnational movement. Their human face appears to us, as people who "speak with conviction and quiet, self-reflective dignity of their efforts to live a full, enlightened life" ( $p, 160)$. Chapter 6 is a discussion of the conflicting narratives produced by both Falun Gong and the Chinese state since the 1999 repression, which will be useful for readers trying to evaluate the wildly opposing claims made by both sides. Overall, Ownby accords more sympathy to Falun Gong sources (no matter how much one may dislike or disagree with Falun Gong, there is no moral justification for jailing or torturing its followers), while noting that, in an increasingly desperate attempt to keep the media's attention, their tendency to exxagerate and sensationalize has had the opposite effect of alienating journalists and dampening Falun Gong's credibility in the eyes of public opinion.

The conclusion proposes to discard the dominant paradigm of modern Chinese historiography, which has stressed the role of revolution and modernization, and challenges historians and scholars of Chinese society and politics to reconsider the continued influence of religiosity in the narrative of contemporary Chinese history.

Overall, Falun Gong and China's Future is the best academic work on Falun Gong available today. I have only two minor criticisms: (1) the title is catchy but the book has little to say about China's future, except to imply that popular religion will play a big role; (2) Ownby and I disagree on the role of Li Hongzhi's ideas in leading to the conflict between Falun Gong and the CCP; for lack of space, I can only refer readers to his discussion of our difference on pp. 21-22 and p.169, in reference to my Qigong Fever: Body, Science and Utopia in China (New York: Columbia University Press, 2008), chap. 8. [DP note: see discussion below].

\section{Hong Kong University}

DAVID A. PALMER

Section unpublished owing to lack of space:

My only quibble with the author's conclusions concerns our slightly different interpretations of how the conflict between Falungong and the CCP was triggered, an issue he discusses at the end of the Introduction (pp. 19-22), in reference to my own 
work on this theme (Qigong Fever: Body, Science and Utopia in China, Columbia University Press, 2008). While I have attributed a major role to Li Hongzhi's ideas and ideology in what I have qualified as the "inexorable" evolution of Falungong toward a confrontation with the Chinese state, Ownby explains the conflict more in terms of contingent factors, such as the fact that he lived overseas, away from the masses of his followers, from 1996 onwards, and that he "miscalculated" or "overplayed his hand" when lauching or authorizing the Zhongnanhai demonstration of April 24, 1999. He also disagrees with my interpretation of the 300 sit-ins and demonstrations held by Falungong practitioners between 1996 and 1999 at the offices of media outlets and local authorities, as part of an escalating pattern of confrontation which led to the Zhongnanhai demonstration and, after the crackdown of July 1999 and by the early 2000's, toward an increasingly explicit campaign to undermine and finally induce the collapse of the CCP itself. My interpretation may well be wrong, and I leave it to readers to make their own judgement. However, if we look at the behaviour of other qigong and religious groups during those crucial years, we can see a range of responses to similar pressures from the Chinese state. For example, there were dozens of other qigong groups with mass followings in the late 1990's, some of which were led by masters who were also in overseas exile; many of these groups were criticized in the Chinese media and their practitioners harrassed by the authorities, yet none engaged in repeated campaigns to publicly challenge the media and local authorities around the country. During the same period, the number of Protestant Christians in China also grew by the millions, and undoubtedly surpassed the number of Falungong practitioners. Most of them worshipped in unregistered house churches and were often harrassed by the authorities, yet they generally did their utmost to minimize the authorities' fears and to avoid any collective behaviour which could be interpreted as confrontational by the authorities. Clearly, different groups have different patterns of behaviour under similar circumstances - and while contingent factors necessarily play a role in their divergent historical trajectories, I do consider that in the case of people who religiously follow a set of beliefs, these beliefs, and the ideas and guidance given by the leader, cannot but influence their collective behaviour. Different sets of belief and leadership are one, though not the only, explanatory factor for the different patterns of behaviour of different groups. Falun Gong's collective pattern of behaviour is consistent with the Falun Gong belief system and the ideas and guidance given by Li Hongzhi, and there are real differences between these and the majority of qigong groups - differences which struck me the moment I first opened Li Hongzhi's books in 1998 while I was doing my research in China, before the crackdown, when I hadn't even heard of the demonstrations going on. Therefore, it is only reasonable to conclude that there is a connection between between the different belief systems and leadership of Falun Gong and other qigong groups, and their different patterns of behaviour. 
